\title{
Agro-Environmental Benefit and Risk of Manure- and Bone Meal-Derived Pyrogenic Carbonaceous Materials as Soil Amendments: Availability of PAHs, PTEs, and $\mathbf{P}$
}

\author{
Vladimír Frišták ${ }^{1, *}$, Martin Pipiška ${ }^{1}$, Gerhard Soja ${ }^{2}{ }^{\circledR}$, Alena Klokočíková Packová ${ }^{3}$, \\ Michal Hubeňák ${ }^{4}$ and Magdaléna Kadlečíková 5 \\ 1 Department of Chemistry, Trnava University in Trnava, 91843 Trnava, Slovak; martin.pipiska@truni.sk \\ 2 Energy Department, Austrian Institute of Technology GmbH, 3430 Tulln, Austria; Gerhard.Soja@ait.ac.at \\ 3 Department of Chemistry, Matej Bel University, 97401 Banská Bystrica, Slovak; packova.a@gmail.com \\ 4 Department of Inorganic Chemistry, Comenius University in Bratislava, 81219 Bratislava, Slovak; \\ michalhubenak@gmail.com \\ 5 Faculty of Electrical Engineering and Information Technology, Slovak University of Technology in Bratislava, \\ 81219 Bratislava, Slovak; magdalena.kadlecikova@stuba.sk \\ * Correspondence: fristak.vladimir.jr@gmail.com; Tel.: +421-33-592-1459
}

Received: 29 October 2019; Accepted: 22 November 2019; Published: 24 November 2019

\begin{abstract}
The worldwide boom of biochar and pyrogenic carbonaceous material application as a potential soil additive has brought about not only agricultural benefits such as enhanced crop yield, nutrients supply $(\mathrm{P})$, and soil organic carbon increase, but also, on the other hand, environmental risk of organic (polycyclic aromatic hydrocarbons (PAHs)) and potentially toxic element (PTE) penetration into arable soils. Therefore, our study assessed pyrogenic carbonaceous materials (PCM) produced from the P-rich feedstocks—chicken manure (CM) and bone meal (BM)—as promising and safe alternatives for inorganic $\mathrm{P}$ fertilizers. Pyrogenic materials produced in the process of slow pyrolysis at residence time $2 \mathrm{~h}, 400$ and $500{ }^{\circ} \mathrm{C}$, were characterized by determination of $\mathrm{pH}$, electrical conductivity (EC), elemental analysis of total C, H, N, S scanning electron microscopy (SEM), total content of P, selected potentially toxic elements (PTEs), and available forms of PTEs and $\mathrm{P}$ by diethylenetriaminepentaacetic acid (DTPA) and calcium-acetate-lactate (CAL) extractions. CMPCM4, CMPCM5, BMPCM4, and BMPCM5 were characterized by determination of total 16 US-EPA (U.S. Environmental Protection Agency) PAHs by toluene extraction protocol and available concentrations by Tenax resin approach. Additionally, CMPCM4, CMPCM4, BMPCM4, and BMPCM5 were tested in earthworm avoidance test with Eisenia foetita and short-term rye-seedling germination test. Obtained results showed decreasing of total carbon in the order of BM > BMPCM4 > BMPCM5 and increasing in the order of $\mathrm{CM}<\mathrm{CMPCM} 4<\mathrm{CMPCM}$. Total phosphorus content increased from $56.8 \pm 1.7 \mathrm{~g} \mathrm{~kg}^{-1}$ (BM) to $85.2 \pm 4.2 \mathrm{~g} \mathrm{~kg}^{-1}$ (BMPCM4) to $110.5 \pm 7.0 \mathrm{~g} \mathrm{~kg}^{-1}$ (BMPCM5). In the case of chicken manure-derived pyrogenic materials, total phosphorus content increased in the order of $\mathrm{CM}\left(22.9 \pm 2.0 \mathrm{~g} \mathrm{~kg}^{-1}\right)<$ CMPCM4 $\left(37.0 \pm 4.5 \mathrm{~g} \mathrm{~kg}^{-1}\right)<$ CMPCM5 $\left(40.0 \pm 3.4 \mathrm{~g} \mathrm{~kg}^{-1}\right)$. Availability of selected PTEs and $\mathrm{P}$ decreased in pyrogenic materials compared to feedstock. Total concentration of $\sum 16$-US-EPA PAHs in BMPCM4 and BMPCM5 was $3.92 \mathrm{mg} \mathrm{kg}^{-1}$; CMPCM4, $7.33 \mathrm{mg} \mathrm{kg}^{-1}$; and CMPCM, $6.69 \mathrm{mg} \mathrm{kg}^{-1}$. The Tenax-available $\sum 16$-PAHs showed concentrations of $0.53 \mathrm{mg} \mathrm{kg}^{-1}$ for BMPCM4, $0.26 \mathrm{mg} \mathrm{kg}^{-1}$ for BMPCM5, $1.13 \mathrm{mg} \mathrm{kg}^{-1}$ for CMPCM4, and $0.35 \mathrm{mg} \mathrm{kg}^{-1}$ for CMPCM5. Total $\mathrm{P}$ concentrations determined in rye aboveground tissues showed the highest accumulation ability in the case of CMPCM5 compared to other samples. Pyrogenic carbonaceous materials produced from chicken manure and bone meal at 400 and $500{ }^{\circ} \mathrm{C}$ have the potential to be $\mathrm{P}$ slow release fertilizers and may be ecologically safe.
\end{abstract}


Keywords: pyrolysis; PAHs; PTEs; P fertilizer; soil amendment

\section{Introduction}

Agricultural soils globally are at risk of losing organic carbon by intensive soil tillage and ineffective cropping practices. About $45 \%$ of all European mineral soils have low to very low organic carbon contents $(0-2 \%)$ [1]. Low soil content increases the vulnerability of soils to biodiversity decline, compaction, erosion, reduced fertility, and low water holding capacity. The importance of soil organic carbon is based on its role as a primary constituent of soil organic matter that has a stable fraction known as humus. Additionally, sustained soil fertility is not achievable without the appropriate supply of nutrients for vegetation. Among the essential elements necessary for plant growth, phosphorus is one of the most critical macronutrients [2]. Phosphorus is mined from rock phosphate, which is characterized by extremely uneven geographical distribution, and constitutes a limited resource that is at risk of exhaustion in the course of this century or the next [3]. As a result, fertilizer products that consider the demand of crops for both nutrient and soil organic carbon can be efficient soil amendments with properties not easily simulated by conventional mineral or organic fertilizers. Development of such innovative products requires feedstock-specific carbonization steps that will modify the labile carbon of wastes and residues into stable organic carbon compounds with mean soil residence times of decades to centuries [4].

The application of modern processing technologies such as pyrolysis and carbonization using biogenic waste materials has the potential to develop combined solutions for organic carbon and phosphorus problems of present and future agriculture and food production. Pyrolysis is a carbonization technology that converts biomass or other organic materials thermochemically into predominantly stable, recalcitrant organic carbon compounds. The process requires an inert atmosphere with low to no oxygen, a temperature range of $300-1000^{\circ} \mathrm{C}$, and residence time from seconds to several hours [5-8]. Produced pyrogenic carbonaceous materials contain concentrated (two to three times) content of total carbon and other elements (phosphorus, calcium, potassium) in comparison to the feedstock [9], however, with the possible amplification of potentially toxic elements (PTEs) such as cadmium, zinc, lead, and copper. Additionally, incomplete combustion and the method of feedstock pyrolysis are often responsible for significant levels of coproduced polycyclic aromatic hydrocarbons (PAHs) in pyrogenic carbonaceous products [10]. Processes of dehydrogenation, dealkylation, cyclization, and aromatization of polymers are responsible for PAH structure and formation during pyrolysis at lower temperatures [11]. Additionally, the pyrogenic carbonaceous materials can often be contaminated by the re-condensation of PAHs from gases and vapours released during thermochemical conversion [12]. Pyrogenic materials used as soil fertilizers, therefore, may act as a source of PAH. Our previous studies [6] confirmed the impact of thermochemical treatment on extractable concentrations of aromatic compounds from sewage sludge-derived pyrogenic carbonaceous materials. Wang et al. [13] highlighted the importance of PAH monitoring in biochar-based soil amendments concerning plant contamination and human cancer risk. Authors have indicated that the total concentrations of 16 US-EPA (U.S. Environmental Protection Agency) PAH structures ranged from 638 to $12,347 \mu \mathrm{g} \mathrm{kg}^{-1}$ depending on production parameter, and that biochar application increased PAH accumulation in vegetable due to root exudates that enhanced aromatic release from biochars [13].

Conventional feedstocks such as wood waste or plant residues are thermochemically converted to high carbon concentrated products with very limited content of nutrients [14]. Therefore production of pyrogenic materials as potential soil fertilizers requires the use of reachable and, on nutrients, rich feedstock such as manures or animal residues [15]. Applied materials have to be closely monitored for potential ecotoxicity on the basis of organic and inorganic pollutant availability and mobility. The use of bone and meat meal in animal feeds was prohibited after the bovine spongiform encephalopathy crisis throughout the EU countries [16]. The utilization of low-risk and safe material from healthy 
animals is allowed as soil fertilizer or pet feed, and thus the enormous amount of bone meal produced by the food processing industry each year represents a promising input material. Furthermore, the bone meal material is conveniently rendered safe through the thermal treatment, which destroys pathogens and converts material into added-value product [17]. Biochar derived from animal bone meal is a high-calcium and phosphorus-rich material with low carbon content but with high agronomic efficiency such as crop yield increase [18]. Additionally, this kind of biochar has shown remediation potential for cadmium immobilization in contaminated soils [19]. Intensification of animal husbandry production can lead to a large concentration of animals in small areas, excessive amounts of manure, and subsequent environmental problems such as nutrient leaching into water bodies, methane emissions, and odour pollution [20]. Therefore, thermochemical stabilization of these materials could reduce the amount of nitrogen and phosphorus entering streams, ponds, or lakes, and convert carbon fractions into more stable forms. Nevertheless, more research is needed to critically evaluate the effect of the pyrolysis treatment on carbon content, nutrient availability, and potential contaminant mobility in manure- and bone meal-derived pyrogenic carbonaceous materials.

The aims of the present research were to characterize (i) agricultural and environmental benefits, including phosphorus availability, carbon fixation, and enhanced plant yield production of bone meal and chicken manure-derived biochars; and (ii) evaluate the concentrations of organic (PAHs) and inorganic (PTEs) and their mobility and penetration from pyrogenic material-based fertilizers and into the soil environment as a potential risk.

\section{Materials and Methods}

\subsection{Biochar Production and Physicochemical Characterization}

Commercially available feedstock bone meal (BM) based on livestock residues (AIT, Austria) was oven dried at $60^{\circ} \mathrm{C}$ for $72 \mathrm{~h}$. Fresh chicken manure (CM) obtained from a local poultry farm (Tulln, Austria) was lyophilised in a lab-scale freeze-drying system using conditions of $0.2-0.4 \mathrm{mbar}$ of pressure, condenser temperature of $-45^{\circ} \mathrm{C}$, chamber temperature from $-15^{\circ} \mathrm{C}$ to $-5{ }^{\circ} \mathrm{C}$, and residence time of 14 days. Both feedstock materials were thermochemically converted using slow pyrolysis process at temperatures of $400{ }^{\circ} \mathrm{C}$ and $500{ }^{\circ} \mathrm{C}$ (heating rate $30^{\circ} \mathrm{C} \mathrm{min}$ ) for $2 \mathrm{~h}$ of residence time in a modified lab-scale pyrolysis reactor under $\mathrm{N}_{2}$ atmosphere $\left(2 \mathrm{~L} \mathrm{~min}^{-1}\right)$ to ensure strict anoxic conditions. Uniform conditions of each batch were ensured by thermochemical sensors and technological process control unit. The resulting pyrogenic carbonaceous materials BMPCM4, CMPCM4, BMPCM5, and CMPCM5 with production yields $30 \%-40 \%$ were ground, sieved to achieve uniform fractions $(<200 \mu \mathrm{m}$ and $<2 \mathrm{~mm}$ ), and stored in polypropylene boxes under dry and $\operatorname{cool}\left(4^{\circ} \mathrm{C}\right)$ conditions. Prior to each analysis, BMPCM4, CMPCM4, BMPCM5, and CMPCM5 samples were thoroughly mixed in a lab-shaker. The total contents of $\mathrm{C}, \mathrm{H}$, and $\mathrm{N}$ within the samples were determined using Elemental Analyzer (CHNS-O EA 1108, Carlo Erba Instruments, Milan, Italy). The active $\mathrm{pH}$ values of samples were measured after mixing samples with deionized water (ratio 1:15 m:v) for $1 \mathrm{~h}$, and $1 \mathrm{~h}$ of stabilization. Electrical conductivities (EC) of samples were measured in deionized water (1:10 m:v) after $24 \mathrm{~h}$ of mixing. The characterization experiments were conducted for each material using three replicates. The morphological structures of BMPCM4, BMPCM5, CMPCM4, and CMPCM5 were captured by scanning electron microscopy (SEM) using an electron microscope JEOL JSM7500F (Tokyo, Japan) equipped with a field emission electron source using a $10 \mathrm{kV}$ accelerating voltage and a beam current of $20 \mu \mathrm{A}$. Images were captured in a combined secondary and back scattered electron regimes with a sample-to-detector distance of 10-15 mm.

\subsection{Total and Available Pool of PAH Determination}

Prior each extraction, BMPCM4, CMPCM4, BMPCM5, and CMPCM5 samples were thoroughly mixed in a lab-shaker. The quartering technique to gain an analytically representative sample was applied. The total concentration of 16 structures of polycyclic aromatic 
hydrocarbons according to the EPA priority pollutant list [21] (naphthalene, acenaphtene, acenaphthylene, phenanthrene, fluorene, anthracene, benz[a]anthracene, chrysene, pyrene, fluoranthene, benzo[ $[b]$ fluoranthene, benzo[ $[k]$ fluoranthene, benzo[ $[a]$ pyrene, indeno[1,2,3-cd]pyrene, benzo[ghi]perylene, dibenz[ah]anthracene) within BMPCM4, BMPCM5, CMPCM4, and CMPCM5 were determined by toluene extraction in Soxhlet extraction unit (solid/liquid: $1 / 15,36 \mathrm{~h}, 110^{\circ} \mathrm{C}$ ) [11]. Extracts were cleaned according to Bücheli [22] described in the following steps: $1 \mathrm{~mL}$ of isooctane as keeper was added to extracts, and mixtures were concentrated (rotary vacuum concentrator) and cleaned by DMS/Milli-Q water (9:1, v:v) liquid-liquid partitioning and over $10 \%$ water-deactivated silica gel. A total of 16 EPA PAH concentrations were determined in purified extracts by gas chromatography-mass spectrometry (GC-MS) and high performance liquid chromatography (HPLC). For estimation of physically available forms of 16 EPA PAH desorption, methodology with polymeric adsorbent Tenax TA (Alltech) according Richardson and Aitken [23] was applied. Prior to use, Tenax resin in bead form was cleaned in a Soxhlet extractor by an acetone/hexane mixture (v:v 50:50) for $12 \mathrm{~h}$. Tenax resin was then rinsed with methanol and oven-dried for $24 \mathrm{~h}$ at $40^{\circ} \mathrm{C}$. For the availability test, briefly, $3 \mathrm{~g}$ of BMPCM4, BMPCM5, CMPCM4, and CMPCM5 was placed into $50 \mathrm{~mL}$ centrifuge vials with $30 \mathrm{~mL}$ of deionized water $\left(<0.04 \mu \mathrm{S} \mathrm{cm}^{-1}\right), 0.2 \mathrm{~mL}$ of $2 \mathrm{~mol} \mathrm{~L}^{-1} \mathrm{NaN}_{3}$, and $0.2 \mathrm{~mL} 0.1 \mathrm{~mol} \mathrm{~L}^{-1}$ $\mathrm{HgCl}_{2}$ to inhibit biological activity with $0.5 \mathrm{~g}$ of Tenax beads. Vials were covered with foil to reduce light exposure and placed on a laboratory shaker at $22{ }^{\circ} \mathrm{C}, 60 \mathrm{rpm}$, with 14 days of continuous shaking. The samples were centrifuged (4000 rpm, $20 \mathrm{~min}$ ) and stabilized for $2 \mathrm{~h}$ to separate the Tenax resin and particles of BMPCM4, BMPCM5, CMPCM4, and CMPCM5, respectively. The resin was obtained by raising the suspension surface with deionized water, transferred into tube with deionized water, and vortexed to remove the residues of BMPCM4, BMPCM5, CMPCM4, and CMPCM5. The Tenax resins were extracted with methanol (analytical grade) for $24 \mathrm{~h}$, and the obtained filtered extracts (0.4 mm pore nylon filter) were analysed by GC-MS and HPLC to determine 16 EPA PAHs. For HPLC analysis, the chromatographic apparatus consisted of an Agilent 1100er series model; degasser G1379A; quaternary pump G1311A; column GRACE/Vydac C18 polymeric reversed-phase, $4.6 \times 250 \mathrm{~mm}, 5 \mu \mathrm{m}$; and GRACE/Vydac C18 guard column, $4.6 \times 7.5 \mathrm{~mm}, 5 \mu \mathrm{m}$ was used. The mobile phase, composed of a mixture of ultra-pure water and acetonitrile, varied during time of analysis. The detection was performed with diode array detector $\operatorname{DAD}(\lambda=310 \mathrm{~nm})$ and fluorescence detector FLD $(\operatorname{Ex}=260 \mathrm{~nm}$, $\mathrm{Em}=350 \mathrm{~nm}, 420 \mathrm{~nm}, 440 \mathrm{~nm}, 500 \mathrm{~nm}$ ) detectors. Analytic procedure of $16 \mathrm{PAH}$ determination by HPLC has been described in detail in our previous work [6]. The control analysis of 16 EPA PAH in extracts was conducted by GC-MS, as described in our previous study [24]. The apparatus consisted of an Agilent GC 6890N model, Rtx-5Sil MS capillary column (30 m, $0.25 \mathrm{~mm}$ internal diameter (i.d.), $0.25 \mu \mathrm{m}$ film thickness) from Restek (Bellefonte, PA, USA), and $2 \mathrm{~m}$ Siltek guard column $(0.53 \mathrm{~mm}$ i.d.). Helium was used as a carrier gas at a constant flow of $1 \mathrm{~mL} \mathrm{~min}^{-1}$. GC oven temperature was initially kept at $100{ }^{\circ} \mathrm{C}$ for $1 \mathrm{~min}$, raised at a rate of $5^{\circ} \mathrm{C} \mathrm{min}^{-1}$ to $300{ }^{\circ} \mathrm{C}$, and kept for $15 \mathrm{~min}$. Split less injection volume was $1 \mu \mathrm{L}$. Detection was performed with an Agilent MS 5973i in the electron impact mode with $70 \mathrm{eV}$ ionization energy and single ion monitoring. The mixed $16 \mathrm{EPA} \mathrm{PAH} \mathrm{toluene}$ standard solution (MERCK, Darmstadt, Germany) was used to prepare internal standard solutions of known concentrations.

\subsection{Total and Chemically Extractable Pool of PTE Determination}

Prior to each extraction, BMPCM4, CMPCM4, BMPCM5, and CMPCM5 samples were thoroughly mixed in a lab-shaker. Total $\mathrm{Cd}, \mathrm{Cu}, \mathrm{Fe}$, and $\mathrm{Zn}$ concentrations of BMPCM4, BMPCM5, CMPCM4, and CMPCM5 were determined using inductively coupled plasma-mass spectrometry ICP-MS (Perkin Elmer, Elan DRCe 9000, Shelton, CT, USA) after wet digestion with $\mathrm{HNO}_{3}$ and $\mathrm{H}_{2} \mathrm{O}_{2}$ (Enders and Lehmann, 2012). Mobile fractions of $\mathrm{Cd}, \mathrm{Cu}, \mathrm{Fe}$, and $\mathrm{Zn}$ in BMPCM400, BMPCM500, CMPCM400, and CMPCM500 were determined by diethylenetriaminepentaacetic acid (DTPA) extraction protocol according Lindsay and Norvell [25], followed by ICP-MS analysis. Briefly, $10 \mathrm{~g}$ of pyrogenic materialwith $20 \mathrm{~mL}$ of DTPA extracting solution $\left(0.005 \mathrm{~mol} \mathrm{~L}^{-1}\right.$ diethylenetriaminepentaacetic acid, $0.01 \mathrm{~mol} \mathrm{~L}^{-1}$ 
$\mathrm{CaCl}_{2}$ and $0.1 \mathrm{~mol} \mathrm{~L}^{-1}$ triethanolamine, with a $\mathrm{pH}$ of 7.3 ) was shaken for $2 \mathrm{~h}$ at $180 \mathrm{rpm}$. The experiments were conducted for each material using three replicates.

\subsection{Earthworm Avoidance Test}

The earthworm avoidance test was conducted under modified laboratory conditions (dark room, $15^{\circ} \mathrm{C}$ ) using universal soil substrate (Einheitserde ED63, $\mathrm{pH}$ 6.8) [26,27]. Prior to use, soil substrate was oven-dried at $50{ }^{\circ} \mathrm{C}$ for 5 days, passed through a $2 \mathrm{~mm}$ standardized test sieve (RETSCH, Haan, Germany), homogenized, and moistened to $30 \%$ dry matter (DM) moisture content. As an experimental unit, polyvinylchloride (PVC) vessels with a diameter of $15 \mathrm{~cm}$ and height of $20 \mathrm{~cm}$ were used. Units were divided into two equal sections by a vertically introduced PVC divider. One half of each vessel was filled with non-amended (control) substrate, whereas the other half was filled with $1 \%$ and $3 \%$ (w:w) BMPCM-, BMPCM5-, CMPCM4-, and CMPCM5-amended substrate. Particle size of $<2 \mathrm{~mm}$ of pyrogenic materials was used for the amendments. The divider was subsequently removed and 10 red worms Eisenia foetida (worm farm) were randomly placed. This species was chosen as it commonly occurs in organic rich soils [28]. Experimental units were covered by perforated plastic wrap in order to prevent escape. During the 14 day incubation period, the position and orientation of vessels were randomly changed and soil moisture was checked by weighing the units and replenishing the weight loss with deionized water. The experiment was conducted for each material and amendment ratio using five replicates. The experiment was concluded by inserting the divider into its original position, emptying out the different parts of vessels, and counting the earthworms found in respective compartments. Earthworms damaged by the divider were not considered. The percentage of avoidance was calculated according to the following equation:

$$
X_{\text {avoidance }}=-100\left(n_{c}-n_{t}\right) / N
$$

where $X_{\text {avoidance }}$ is the avoidance in percent, $n_{c}$ is the number of earthworms in the nonamended (control) soil (mean of five replicates), $n_{t}$ is the number of earthworms in the amended soil (mean of five replicates), and $N$ is the total number of earthworms in experimental unit.

\subsection{Phosphorus Content, Mobility, and Availability}

The total phosphorus content in BMPCM4, BMPCM5, CMPCM4, and CMPCM5 was determined by ICP-MS (Perkin Elmer, Elan DRCe 9000, USA) after wet digestion with $\mathrm{HNO}_{3}$ and $\mathrm{H}_{2} \mathrm{O}_{2}$ [29]. For determination of labile phosphorus forms, the calcium-acetate-lactate (CAL) extraction protocol was used [30], followed by P-determination in extracts by ICP-MS. Briefly, $1 \mathrm{~g}$ of BMPCM400, BMPCM500, CMPCM400, and CMPCM500 was shaken with $20 \mathrm{~mL}$ of CAL extractant $\left(0.05 \mathrm{~mol} \mathrm{~L}^{-1}\right.$ calcium lactate $+0.05 \mathrm{~mol} \mathrm{~L}^{-1}$ calcium acetate $+0.3 \mathrm{~mol} \mathrm{~L}^{-1}$ acetic acid) for $90 \mathrm{~min}$ at $180 \mathrm{rpm}$. The plant available pool of phosphorus in the studied materials was characterized by rye seedlings test [31]. The ryegrass (100 seeds) was grown in experimental $1 \mathrm{~L}$ pots filled with the homogenous mixtures of fine quartz sand and BMPCM400, BMPCM500, CMPCM400, CMPCM500, and commercial inorganic phosphorus fertilizer (IF, $42 \% \mathrm{P}_{2} \mathrm{O}_{5}$, Glatz, Wien, Austria) with particle size $<200 \mu \mathrm{m}$, in ratios of $1 \%$ and $3 \%(\mathrm{w}: \mathrm{w})$ under greenhouse conditions (light period $12 \mathrm{~h}$ light/ $12 \mathrm{~h}$ dark, constant air humidity, $25^{\circ} \mathrm{C}$ ). As a control sample, non-amended quartz sand was used. All amendments were tested using five replicates. The purity of sand was achieved by rinsing with $0.01 \mathrm{~mol} \mathrm{~L}^{-1} \mathrm{HCl}$ and deionized water (electrical conductivity EC $<0.04 \mu \mathrm{S} \mathrm{cm}^{-1}$ ). The content of extractable $\mathrm{P}$ from purified sand was under limit of detection (LOD) of analytical method. The pots were irrigated using P-free Hoagland solution including all others nutrients to keep the water capacity at constant value during the 17 day experimental period. The position of sample replicates within each experimental block was randomized. At the end of experiment, aboveground (leaf tissues) and underground (roots) of ryegrass were harvested, washed with deionized water, separated from sand and biochar particles, and dried at $60^{\circ} \mathrm{C}$ for 14 days. Plant 
materials were characterized for total $\mathrm{P}, \mathrm{Cd}, \mathrm{Cu}, \mathrm{Fe}$, and $\mathrm{Zn}$ contents by ICP-MS after previous wet digestion with $\mathrm{HNO}_{3}$ and $\mathrm{HClO}_{4}$.

\section{Results}

\subsection{Pyrogenic Material Characterization}

Feedstock mass loss during pyrolysis corresponded to an increase in process temperature with production yields of $46 \%$ for BMPCM4, 35\% for BMPCM5, 47\% for CMPCM4, and 40\% for CMPCM5.

The carbon and nitrogen residing within the volatile chemical components of bone meal-derived pyrogenic materials were preferentially lost compared to the less volatile elements that concentrated under pyrolysis conditions (Table 1). Chicken manure-derived pyrogenic material produced at $500{ }^{\circ} \mathrm{C}$ showed decreased total nitrogen content and a slight increase in total content of carbon compared to CMPCM4 and thus lower volatilization of carbon-based components. Studied pyrogenic materials had stronger alkalinity character.

Table 1. Physicochemical characteristics of bone meal (BM), chicken manure (CM), and derived pyrogenic carbonaceous materials produced at $400{ }^{\circ} \mathrm{C}(\mathrm{BMPCM} 4, \mathrm{CMPCM} 4)$ and $500{ }^{\circ} \mathrm{C}(\mathrm{BMPCM}$, $\mathrm{CMPCM} 5)$. All measurements were conducted in triplicate (mean $\pm \mathrm{SD})$.

\begin{tabular}{ccccccc}
\hline Sample & $\mathbf{p H}$ & $\mathbf{E C}\left(\mathbf{m S ~ c m}^{-\mathbf{1}}\right)$ & $\mathbf{C}_{\text {tot }} \mathbf{( \% )}$ & $\mathbf{H}_{\text {tot }} \mathbf{( \% )}$ & $\mathbf{N}_{\text {tot }}(\mathbf{\%})$ & $\mathbf{S}_{\text {tot }}(\mathbf{\%})$ \\
\hline BM & $6.5 \pm 0.1$ & $0.6 \pm 0.1$ & $39.8 \pm 0.7$ & $6.1 \pm 0.4$ & $7.7 \pm 0.4$ & $0.5 \pm 0.1$ \\
BMPCM4 & $9.8 \pm 0.1$ & $4.7 \pm 0.1$ & $33.9 \pm 0.2$ & $2.5 \pm 0.1$ & $5.2 \pm 0.3$ & $0.2 \pm 0.1$ \\
BMPCM5 & $10.1 \pm 0.1$ & $5.0 \pm 0.1$ & $30.3 \pm 0.1$ & $1.3 \pm 0.0$ & $5.0 \pm 0.3$ & $0.2 \pm 0.1$ \\
CM & $7.6 \pm 0.1$ & $0.8 \pm 0.1$ & $37.1 \pm 0.2$ & $5.3 \pm 0.2$ & $3.8 \pm 0.2$ & $0.8 \pm 0.1$ \\
CMPCM4 & $9.7 \pm 0.1$ & $4.1 \pm 0.1$ & $44.8 \pm 0.1$ & $2.6 \pm 0.1$ & $4.4 \pm 0.3$ & $0.9 \pm 0.1$ \\
CMPCM5 & $10.1 \pm 0.2$ & $5.0 \pm 0.3$ & $46.3 \pm 0.1$ & $1.6 \pm 0.1$ & $4.1 \pm 0.3$ & $0.8 \pm 0.1$ \\
\hline
\end{tabular}

The morphology and surface structure of BMPCM and CMPCM obtained by SEM revealed preferentially amorphous particles of BMPCM (Figure 1a,b). The structural characteristics of finely and coarsely ground animal bones reflected the final structure of derived bone meal-derived pyrogenic material. SEM images of CMPCM (Figure 1c,d) showed heterogeneous morphology. The mixture of organic matter with minor straw-based litter resulted in the formation of broken fibres, largely amorphous and granular particles. Cellulose fibres are effective carriers and provide surfaces for mineral composite formation during the pyrolysis process.

Comparison of feedstocks and pyrogenic carbonaceous materials produced at 400 and $500{ }^{\circ} \mathrm{C}$ showed differences in chemical composition (Table 2). Total concentrations of $\mathrm{Cd}$ in all tested materials were lower than the detection limit of the applied analytical method. Total content of $\mathrm{Cu}, \mathrm{Fe}, \mathrm{K}, \mathrm{Mg}$, and $\mathrm{P}$ increased 1.4- to 1.9-fold for both feedstock materials. The difference between materials produced at 400 and $500{ }^{\circ} \mathrm{C}$ was negligible. Total $\mathrm{Zn}$ content in BMPCM4 and CMPCM4 doubled compared to input feedstocks. Pyrogenic materials produced at $500{ }^{\circ} \mathrm{C}$ contained three times the $\mathrm{Zn}$ content than raw bone meal and chicken manure.

The DTPA-available concentrations provided important information to estimate bioavailability of metal and mettaloids in soil and soil amendments (Table 3). Comparison of DTPA-extractable amounts of $\mathrm{Cd}, \mathrm{Cu}, \mathrm{Fe}$, and $\mathrm{Zn}$ from feedstocks and pyrogenic carbonaceous materials produced at 400 and $500{ }^{\circ} \mathrm{C}$ showed a significant decrease in mobile metal forms. In bone meal-derived pyrogenic carbonaceous materials BMPCM4 and BMPCM5, the DTPA-extractable Cd was lower than the detection limit of the analytical method $\left(<0.05 \mathrm{mg} \mathrm{kg}^{-1}\right)$. Extractable $\mathrm{Cu}$ decreased about $6 \%-34 \%$, Fe $67 \%-80 \%$, and $\mathrm{Zn} 18 \%-33 \%$. In the case of chicken manure-derived pyrogenic carbonaceous materials, a decreased availability of $\mathrm{Cu}$ of about $40 \%-56 \%$, Fe $54 \%-72 \%$, and $\mathrm{Zn} 25 \%-35 \%$ was observed. Phosphorus available forms in BMPCM4, BMPCM5, CMPCM4, and CMPCM5 tested by CAL-extraction protocol showed a comparable trend for both feedstocks in reduction of extractable phosphorus and revealed the option to mitigate diffuse P-losses in soil. 
a
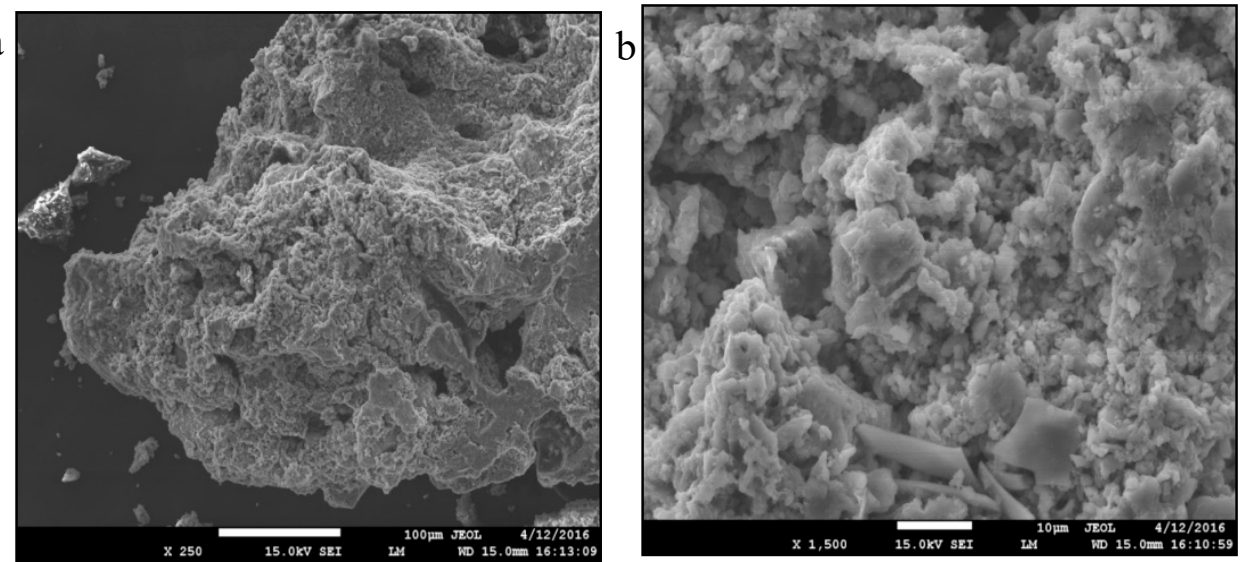

C
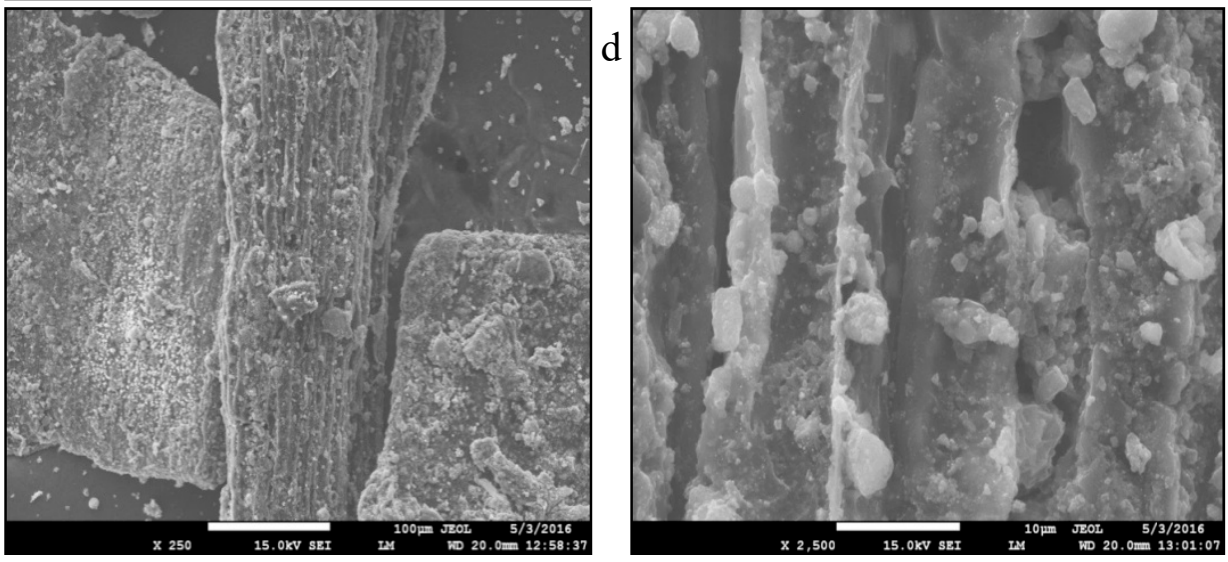

Figure 1. Scanning electron microscophic (SEM) images of BMPCM at magnifications of $250 \times$ (a) and $1500 \times(\mathbf{b})$, and CMPCM at magnifications of $250 \times(\mathbf{c})$ and $2500 \times(\mathbf{d})$.

Table 2. Total concentrations of $\mathrm{Cd}, \mathrm{Cu}, \mathrm{Fe}, \mathrm{K}, \mathrm{Mg}, \mathrm{P}, \mathrm{Zn}$, and calcium-acetate-lactate (CAL) extractable concentrations of $\mathrm{P}$ in bone meal (BM), chicken manure (CM), and derived pyrogenic carbonaceous materials produced at $400{ }^{\circ} \mathrm{C}(\mathrm{BMPCM} 4, \mathrm{CMPCM} 4)$ and $500{ }^{\circ} \mathrm{C}(\mathrm{BMPCM} 5, \mathrm{CMPCM} 5)(\mathrm{mean} \pm \mathrm{SD})$.

\begin{tabular}{|c|c|c|c|c|c|c|c|}
\hline Sample & $\mathrm{Cd}\left(\mathrm{mg} \mathrm{kg}^{-1}\right)$ & $\mathrm{Cu}\left(\mathrm{mg} \mathrm{kg}{ }^{-1}\right)$ & $\mathrm{Fe}\left(\mathrm{g} \mathrm{kg}^{-1}\right)$ & $\mathrm{K}\left(\mathrm{g} \mathrm{kg}^{-1}\right)$ & $\operatorname{Mg}\left(\mathrm{g} \mathrm{kg}^{-1}\right)$ & $P\left(g_{k g}^{-1}\right)$ & $\mathrm{Zn}\left(\mathrm{g} \mathrm{kg}^{-1}\right)$ \\
\hline $\mathrm{BM}$ & $<0.05$ & $12.4 \pm 0.4$ & $0.6 \pm 0.4$ & $8.2 \pm 0.4$ & $2.8 \pm 0.2$ & $56.8 \pm 1.7$ & $0.1 \pm 0.0$ \\
\hline BMPCM4 & $<0.05$ & $19.2 \pm 0.7$ & $0.9 \pm 0.1$ & $11.4 \pm 0.2$ & $4.7 \pm 0.3$ & $85.2 \pm 4.2$ & $0.2 \pm 0.0$ \\
\hline $\mathrm{CM}$ & $<0.05$ & $67.1 \pm 3.2$ & $1.4 \pm 0.1$ & $30.2 \pm 0.6$ & $12.8 \pm 0.1$ & $22.9 \pm 2.0$ & $0.6 \pm 0.1$ \\
\hline CMPCM4 & $<0.05$ & $98.8 \pm 7.1$ & $2.0 \pm 0.1$ & $44.2 \pm 0.5$ & $17.0 \pm 0.4$ & $37.0 \pm 4.5$ & $1.1 \pm 0.1$ \\
\hline CMPCM5 & $<0.05$ & $109.2 \pm 9.7$ & $2.2 \pm 0.1$ & $44.7 \pm 0.4$ & $18.0 \pm 1.2$ & $40.0 \pm 3.4$ & $1.2 \pm 0.2$ \\
\hline
\end{tabular}

Table 3. DTPA extractable concentrations of $\mathrm{Cd}, \mathrm{Cu}, \mathrm{Fe}, \mathrm{P}, \mathrm{Zn}$, and CAL extractable concentrations of $\mathrm{P}$ in bone meal (BM), chicken manure (CM), and derived pyrogenic carbonaceous materials produced at $400{ }^{\circ} \mathrm{C}$ (BMPCM4, CMPCM4) and $500{ }^{\circ} \mathrm{C}(\mathrm{BMPCM} 5, \mathrm{CMPCM} 5)$ (mean $\left.\pm \mathrm{SD}\right)$.

\begin{tabular}{|c|c|c|c|c|c|}
\hline Sample & $\mathrm{Cd}_{\mathrm{DTPA}}\left(\mathrm{mg} \mathrm{kg}^{-1}\right)$ & $\mathrm{Cu}_{\text {DTPA }}\left(\mathrm{mg} \mathrm{kg}^{-1}\right)$ & $\mathrm{Fe}_{\text {DTPA }}\left(\mathrm{mg} \mathrm{kg}^{-1}\right)$ & $P_{\mathrm{CAL}}\left(\mathrm{mg} \mathrm{kg}^{-1}\right)$ & $\mathrm{Zn}_{\text {DTPA }}\left(\mathrm{mg} \mathrm{kg}^{-1}\right)$ \\
\hline$B M$ & $<0.05$ & $1.8 \pm 0.1$ & $63.8 \pm 3.5$ & $815.6 \pm 29.5$ & $54.7 \pm 2.6$ \\
\hline BMPCM4 & $<0.05$ & $1.7 \pm 0.1$ & $21.4 \pm 1.5$ & $654.8 \pm 22.5$ & $44.7 \pm 2.1$ \\
\hline ВMPCM5 & $<0.05$ & $1.2 \pm 0.1$ & $11.5 \pm 0.8$ & $379.7 \pm 16.9$ & $37.1 \pm 2.4$ \\
\hline $\mathrm{CM}$ & $<0.05$ & $7.4 \pm 0.2$ & $84.4 \pm 5.5$ & $709.4 \pm 29.7$ & $74.7 \pm 7.5$ \\
\hline CMPCM4 & $<0.05$ & $4.4 \pm 0.1$ & $39.0 \pm 2.9$ & $604.4 \pm 33.9$ & $55.9 \pm 3.4$ \\
\hline CMPCM5 & $<0.05$ & $3.3 \pm 0.2$ & $22.9 \pm 2.1$ & $368.7 \pm 21.1$ & $48.5 \pm 2.4$ \\
\hline
\end{tabular}

Our results suggest substantial differences between pyrogenic carbonaceous materials produced at 400 and $500{ }^{\circ} \mathrm{C}$ in extractable concentrations of 16 US-EPA PAHs using toluene extraction in Soxhlet extractor (Table 4 ). Total concentrations of naphthalene represent $>75 \%$ for BMPCM $4,>68 \%$ for BMPCM5, $>88 \%$ for CMPCM4, and >87\% for CMPCM5 of total $\sum 16$ US-EPA PAHs. Determination of 
available forms of PAHs (Table 4) by tenax extraction test revealed the different behaviours of BMPCM4, BMPCM5, CMPCM4, and CMPCM5. Depending on the sample, the content of $\sum 16$ PAHs quantified by Tenax adsorbent beads ranged between $5 \%$ and $16 \%$ of total aromate content defined by toluene extraction protocol (labelled as total). The extraction showed decreased concentrations of $\sum 16$ USEPA PAHs for BMPCM5 (5.2\%) compared to BMPCM4 (15.4\%). For the chicken manure-derived pyrogenic carbonaceous materials, the same trend was confirmed. Available concentrations of $\sum 16$ USEPA PAHs were quantified as $13.6 \%$ for CMPCM4 and $5.8 \%$ for CMPCM5.

Table 4. Total concentrations of naphthalene, acenaphtene, acenaphthylene, phenanthrene, fluorene, anthracene, benz[a]anthracene, chrysene, pyrene, fluoranthene, benzo[ $b]$ fluoranthene, benzo[ $k]$ fluoranthene, benzo[ $a]$ pyrene, indeno[1,2,3-cd]pyrene, benzo[ghi]perylene, and dibenz[ah]anthracene in BMPCM4, BMPCM5, CMPCM4, and CMPCM5 determined by toluene extraction in Soxhlet extraction unit (solid/liquid: $1 / 15,36 \mathrm{~h}, 110{ }^{\circ} \mathrm{C}$ ) and their available concentrations determined by Tenax resin approach (mean $\pm \mathrm{SD}$ ). ND = non-detected.

\begin{tabular}{|c|c|c|c|c|c|c|c|c|}
\hline \multirow{2}{*}{$\begin{array}{c}\text { Sample } \\
\text { Polycyclic Aromatic } \\
\text { Hydrocarbon (PAH) }\end{array}$} & \multicolumn{2}{|c|}{ ВMPCM4 } & \multicolumn{2}{|c|}{ BMPCM5 } & \multicolumn{2}{|c|}{ CMPCM4 } & \multicolumn{2}{|c|}{ CMPCM5 } \\
\hline & $\begin{array}{c}\text { Total } \\
\left(\mu \mathrm{kg}^{-1}\right)\end{array}$ & $\begin{array}{l}\text { Available } \\
\left(\mu \mathrm{gg}^{-1}\right)\end{array}$ & $\begin{array}{c}\text { Total } \\
\left(\mu \mathrm{gg}^{-1}\right)\end{array}$ & $\begin{array}{l}\text { Available } \\
\left(\mu \mathrm{g} \mathrm{kg}^{-1}\right)\end{array}$ & $\begin{array}{c}\text { Total } \\
\left(\mu \mathrm{g} \mathrm{kg}^{-1}\right)\end{array}$ & $\begin{array}{l}\text { Available } \\
\left(\mu \mathrm{gg}^{-1}\right)\end{array}$ & $\begin{array}{c}\text { Total } \\
\left(\mu \mathrm{gg}^{-1}\right)\end{array}$ & $\begin{array}{l}\text { Available } \\
\left(\mu \mathrm{gg}^{-1}\right)\end{array}$ \\
\hline naphthalene & $5566 \pm 24$ & $896 \pm 5$ & $5534 \pm 65$ & $248 \pm 21$ & $3491 \pm 98$ & $478 \pm 21$ & $3427 \pm 65$ & $142 \pm 5$ \\
\hline acenaphtene & $9 \pm 1$ & ND & $5 \pm 0$ & ND & $5 \pm 0$ & ND & $33 \pm 2$ & ND \\
\hline acenaphthylene & $533 \pm 21$ & $73 \pm 3$ & $253 \pm 10$ & $24 \pm 1$ & $195 \pm 6$ & $29 \pm 1$ & $104 \pm 24$ & $51 \pm 3$ \\
\hline phenanthrene & $222 \pm 9$ & $30 \pm 2$ & $255 \pm 8$ & $24 \pm 1$ & $18 \pm 1$ & ND & $24 \pm 1$ & ND \\
\hline fluorene & $444 \pm 16$ & $64 \pm 3$ & $295 \pm 14$ & $25 \pm 10$ & $113 \pm 8$ & $18 \pm 1$ & $84 \pm 3$ & $10 \pm 1$ \\
\hline anthracene & $131 \pm 5$ & $17 \pm 1$ & $88 \pm 3$ & $9 \pm 0$ & $28 \pm 1$ & $9 \pm 0$ & $86 \pm 4$ & $8 \pm 0$ \\
\hline benz $[a]$ anthracene & $61 \pm 2$ & $9 \pm 0$ & $36 \pm 2$ & $3 \pm 0$ & $13 \pm 1$ & ND & $28 \pm 1$ & ND \\
\hline chrysene & $110 \pm 4$ & $15 \pm 1$ & $74 \pm 2$ & $9 \pm 0$ & $21 \pm 1$ & ND & $61 \pm 2$ & $8 \pm 0$ \\
\hline pyrene & $56 \pm 3$ & $9 \pm 0$ & $23 \pm 1$ & ND & $6 \pm 0$ & ND & $17 \pm 1$ & ND \\
\hline fluoranthene & $111 \pm 5$ & $15 \pm 1$ & $73 \pm 2$ & $8 \pm 0$ & $20 \pm 1$ & ND & $60 \pm 2$ & $7 \pm 0$ \\
\hline benzo[b]fluoranthene & $17 \pm 1$ & ND & $7 \pm 0$ & ND & $2 \pm 0$ & ND & $3 \pm 0$ & ND \\
\hline benzo[ $k]$ fluoranthene & $14 \pm 1$ & ND & $7 \pm 0$ & ND & $2 \pm 0$ & ND & $4 \pm 0$ & ND \\
\hline benzo $[a]$ pyrene & $30 \pm 2$ & ND & $18 \pm 0$ & ND & $4 \pm 0$ & ND & $8 \pm 0$ & ND \\
\hline indeno $[1,2,3-c d]$ pyrene & $10 \pm 0$ & ND & $4 \pm 0$ & ND & $2 \pm 0$ & ND & $6 \pm 0$ & ND \\
\hline benzo[ghi]perylene & $3 \pm 0$ & ND & ND & ND & ND & ND & ND & ND \\
\hline dibenz $[a h]$ anthracene & $13 \pm 0$ & ND & $17 \pm 1$ & ND & $3 \pm 0$ & ND & $3 \pm 0$ & ND \\
\hline$\sum 16$ PAHs & 7330 & 1128 & 6689 & 350 & 3923 & 534 & 3928 & 226 \\
\hline
\end{tabular}

\subsection{Avoidance Test}

In the avoidance test, Eisenia foetida actively burrowed in both pyrogenic carbonaceous material-treated and control parts of the vessels, and after 14 days of the tested period, all experimental animals were recovered. After 2 weeks of incubation time, there was a significant difference $(p<0.05)$ in the distribution of the worms between the $1 \%$ and $3 \%$ amendment of BMPCM 4 and BMPCM5, respectively (Figure 2). At 1\% amendment, the earthworms tended to avoid applications of BMPCM4 and BMPCM5. The 3\% treatment showed significant preference for BMPCM4 and BMPCM5 by earthworms. On the other hand, differences between 1\% and 3\% amendment of CMPCM4 were not statistically significant. Both treatments showed preference of earthworms for chicken manure-derived pyrogenic material. The difference between $1 \%$ and $3 \%$ CMPCM 5 treatments was statistically significant $(p<0.05)$ with the most intensive preference of 3\% CMPCM5 by experimental earthworms.

\subsection{Pot Experiment}

The assessment of BMPCM4, BMPCM5, CMPCM4, and CMPCM5 as potential P fertilizers and soil amendments was carried out using a rye seedlings test. After 16 days cultivation, the yield of dry mass increased in the following order: control $<$ P-inorganic fertilizer (IF) $<$ BMPCM5 $<$ CMPCM4 = BMPCM4 $=$ CMPCM5 at $1 \%$ application rate of amendments (Figure 3). On the other hand, after 3\% application rate, the order of increase was P-inorganic fertilizer (IF) $<$ control = BMPCM5 $<$ CMPCM5 $<$ $\mathrm{BMPCM} 4=\mathrm{CMPCM} 4$ (Figure 3 ). The higher application rate of P-inorganic fertilizer caused significant reduction in biomass production and inhibition of rye seed germination in comparison with the $1 \%$ amendment. The contents of total $\mathrm{P}$ in produced biomass showed a significant increase of phosphorus concentrations in all treatments compared to non-amended control (Figure 4A). At 1\% application 
rate, the total phosphorus content in rye biomass increased in the order of control $<$ CMPCM $4<$ BMPCM4 $=$ BMPCM5 $<$ P-inorganic fertilizer $=$ CMPCM5. The highest concentration of $\mathrm{P}$ quantified in rye biomass obtained from $1 \%$ CMPCM5 was $7.1 \mathrm{mg} \mathrm{kg}^{-1}$ (dry weight) The $3 \%$ application showed $\mathrm{P}$ increasing in the order of control $<\mathrm{CMPCM} 4<$ P-inorganic fertilizer $=$ BMPCM4 $=$ BMPCM5 $<$ CMPCM5. The 3\% amendment of CMPCM5 resulted in 2-3 times higher accumulation of phosphorus in rye tissues compared to non-amended control sample.

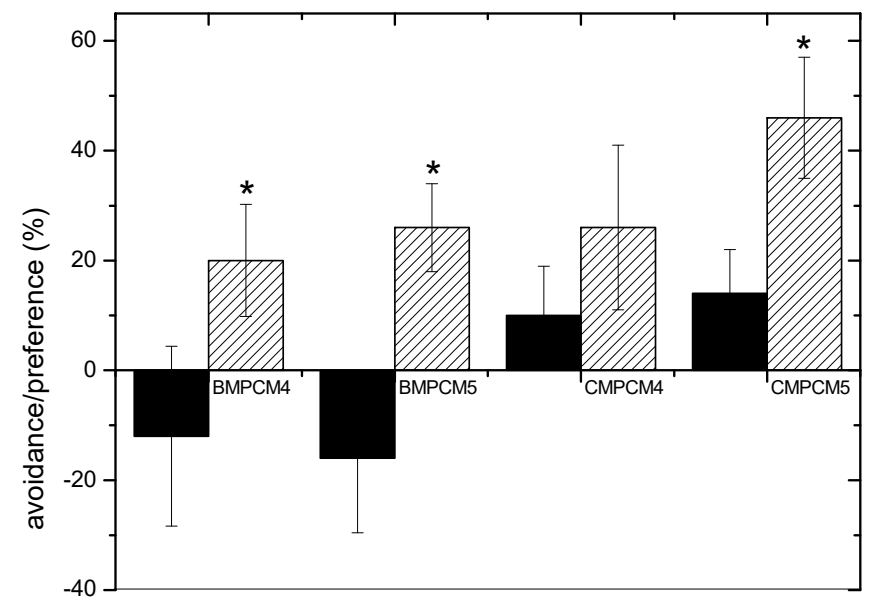

Figure 2. Preference/avoidance $\left(X_{\text {avoid }}\right)$ of Eisenia foetida in 1\% (solid fill) and 3\% (hatched fill) BMPCM4-, BMPCM5-, CMPCM4-, and CMPCM5-amended soil after 2 weeks incubation. Stars indicate a significant difference between application ratio of pyrogenic carbonaceous materials treatments at $p<0.05$ level.

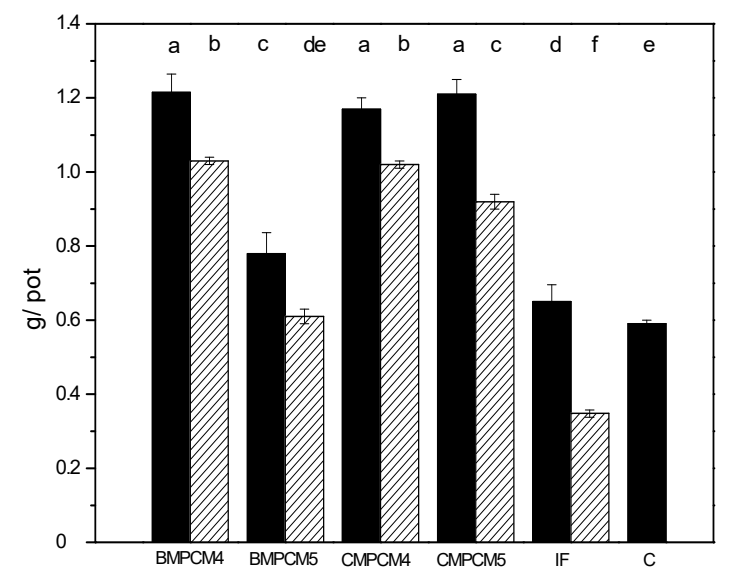

Figure 3. Biomassproduction of ryegrass (dry weight) in pots amended by $1 \%$ (solid fill) and 3\% (hatched fill) BMPCM4, BMPCM5, CMPCM4, CMPCM5, inorganic phosphorus fertilizer (IF), and non-amended soil. Different letters mean statistical significant difference $(p<0.05)$ between studied amendments.

Additionally, the application of BMPCM4, BMPCM4, CMPCM4, and CMPCM5 at both application rates showed significant reduction in $\mathrm{Cu}$ uptake and transfer into aboveground parts of rye compared to the non-amended control (Figure 4B). Total $\mathrm{Cu}$ concentrations in plant tissues obtained from amended samples decreased about $5 \%-43 \%$ compared to control. P-inorganic fertilizer did not show any significant differences to control. Conversely, uptake and accumulation of $\mathrm{Fe}$ in aboveground parts of rye were supported by $1 \%$ and 3\% BMPCM4 amendments with a concentration $>100 \mathrm{mg} \mathrm{kg}-1$ (Figure 4C). BMPCM4, CMPCM4, and CMPCM5 did not significantly increase total Fe content in rye tissues compared to control sample. Determination of total $\mathrm{Zn}$ content in rye showed increase in zinc uptake and accumulation of CMPCM4 and CMPCM5 at 3\% application rate compared to control-concentrations increased from $40 \pm 1.2 \mathrm{mg} \mathrm{kg}^{-1}$ to $47.5 \pm 1.2 \mathrm{mg} \mathrm{kg}^{-1}$. Amendments of 
BMPCM4 and BMPCM5 resulted mainly in the decrease of Zn concentrations in rye tissues of about $12 \%-16 \%$ compared to non-amended control.
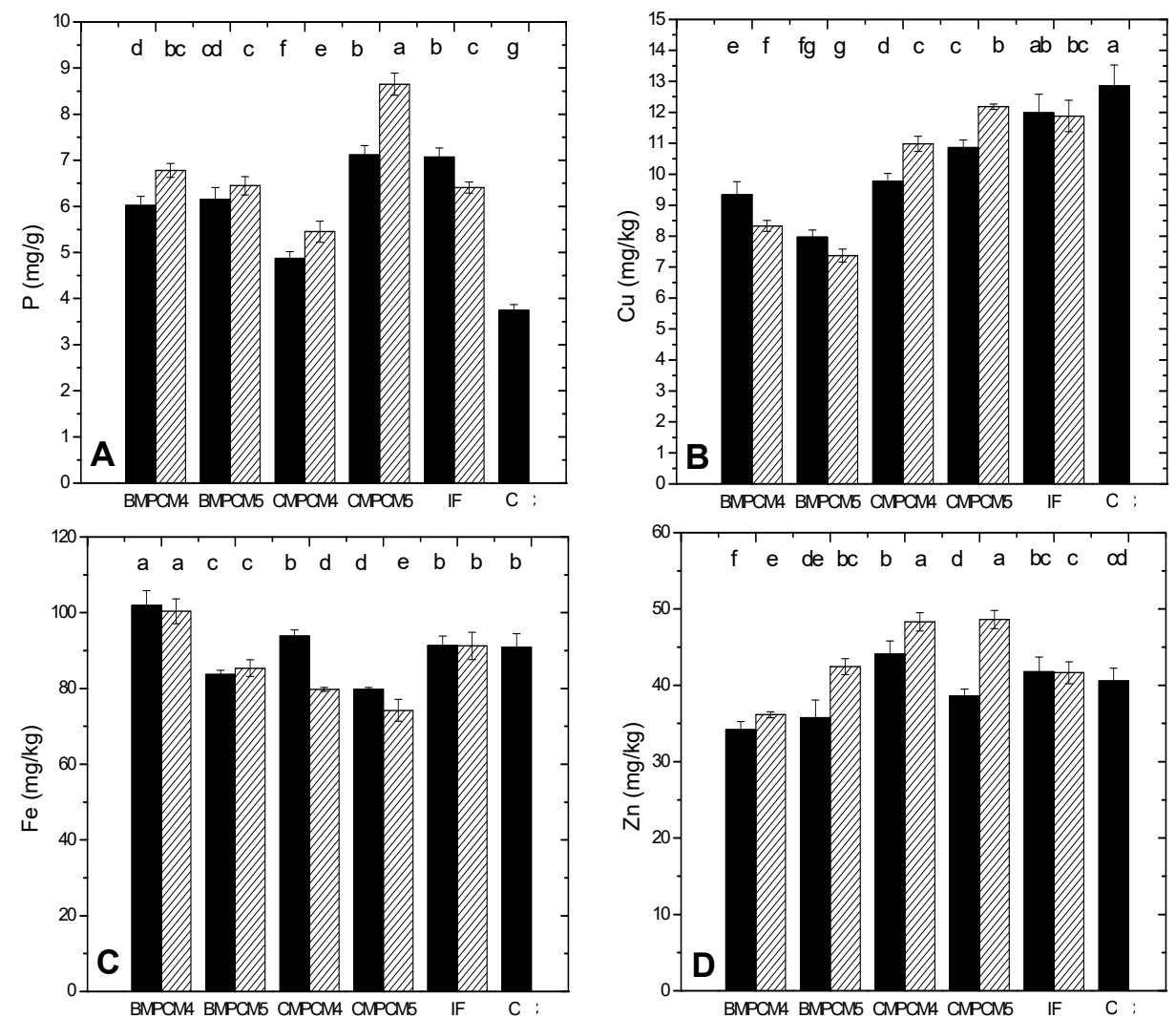

Figure 4. Total concentrations of $\mathrm{P}(\mathrm{A}), \mathrm{Cu}(\mathbf{B}), \mathrm{Fe}(\mathbf{C})$ and $\mathrm{Zn}(\mathbf{D})$ concentrations (mean $\pm \mathrm{SD}$ ) measured in rye grass tissues obtained from pots with $1 \%$ (solid fill) and 3\% (hatched fill) amendment of BMPCM4, BMPCM5, CMPCM4, CMPCM5, and IF after total digestion (method $\mathrm{HNO}_{3}+\mathrm{HClO}_{4}$, in digestion block一temperature program $80^{\circ} \mathrm{C} / 60 \mathrm{~min}, 120^{\circ} \mathrm{C} / 40 \mathrm{~min}, 160{ }^{\circ} \mathrm{C} / 40 \mathrm{~min}, 180{ }^{\circ} \mathrm{C} / 60 \mathrm{~min}, 210^{\circ} \mathrm{C} / 60 \mathrm{~min}$ ) diluted in $61 \%-62 \% \mathrm{HNO}_{3}$ and quantified by ICP-MS. Different letters mean statistical significant difference $(p<0.05)$ between studied amendments.

\section{Discussion}

\subsection{Pyrogenic Carbonaceous Materials Properties}

The assessment of pyrogenic carbonaceous materials as soil amendments and fertilizers represents important issue in current agronomical approaches. Agronomic properties of pyrolysis products can be affected by various parameters such conversion temperature, residence time, heating rate, and feedstock composition [32].

Results of the characterization experiments indicated increased $\mathrm{pH}$ of PCM with pyrolysis peak temperature that was attributed to the processes of volatilization and partitioning of organic acids, decomposition of oxygen-containing functional groups (carboxylic, lactonic, carbonyl, phenolic), dihydroxylation of organic matter, formation of heteroatom groups, and formation of ash residue with high content of alkali and alkaline earth metal carbonates and oxides [14,33]. Alkalic character and $\mathrm{pH}$ values $>10$ of chicken manure-derived biochar produced at 350 and $700{ }^{\circ} \mathrm{C}$ were demonstrated by Hass et al. [14]. The authors discussed the strong influence of feedstock elemental composition on ash mineral composition. The feedstock with initially high ash content results in pyrogenic material of high $\mathrm{pH}$ and liming capacity. Additionally, process temperature affects ash composition of pyrolysis products [6]. Accordingly, European Biochar Certificate EBC [34] pyrogenic carbonaceous materials are characterized by total carbon content $<50 \%$. Elemental analysis showed decrease in total $\mathrm{C}, \mathrm{H}$, 
and $\mathrm{N}$ contents of bone meal-derived pyrogenic carbonaceous materials with increasing pyrolysis temperature. The losses were attributed to the devolatilization of organic compounds and the cleavage of weaker bonds such as $-\mathrm{NH},-\mathrm{OH}$, and $-\mathrm{CH}_{3}$ [17]. These findings agree with our previous studies of sewage sludge [24] and animal residues [15]. Cantrell et al. [34] highlighted reduction of total C with increased temperature by animal manure-derived chars. Increased carbon content in CMPCM5 may be attributed to minor content of straw-based litter in feedstock. Cellulose-based biomaterials during thermochemical conversion increases total carbon content [2]. The higher ash content at CMPCM5 and BMPCM5 was responsible for higher values of BMPCM5 and CMPCM5 EC compared to analogues produced at lower temperatures (Table 1).

Pyrolysis process of bone meal and chicken manure at $500{ }^{\circ} \mathrm{C}$ slightly influenced total 16 USEPA PAHs in comparison with materials produced at $400^{\circ} \mathrm{C}$. All materials, BMPCM4, BMPCM5, CMPCM4, and CMPCM5, were under limit of EBC [35] concerning the content of 16 USEPA PAHs ( $<12 \mathrm{mg} \mathrm{kg}^{-1}$ for basic grade biochar). The effect of pyrolysis treatment confirmed stability and ability of two ring-aromatic structure formations in bone meal and chicken manure during thermochemical conversion, as well as in and temperature dependence. Dai et al. [36] and Búcheli et al. [37] described in detail the main mechanism of polycyclic aromatic hydrocarbon formation during pyrolysis treatment of different biomass. The authors showed pyrosynthesis as a process of gaseous hydrocarbon radical generation by organic matter cracking under $500^{\circ} \mathrm{C}$. Afterwards, these radicals are able to form larger aromatic structures. Lower treatment temperatures can lead to the formation of aromatic structures as a result of biomass conversion by condensation, aromatization, and carbonization [24]. Zielinska and Oleszczuk [38] discussed the main effect of feedstock composition and individual structure contribution to total PAH content in pyrogenic carbonaceous materials. Consideration of the PAH-available pool provides important knowledge in the assessment of pyrogenic material toxicity. Bioavailability of PAHs can be assessed by various methodologies and procedures [10]. The combination of suitable sorption sink and conducting media represents an effective tool in the quantification of freely dissolved and accessible structures of PAHs. According to Oleszczuk [39], the Tenax extraction test can be used as a predictor for free available content of polycyclic aromatic hydrocarbons. Our previous study [24] showed suitability of Tenax resin application in PAH labile pool determination in sludge-derived pyrogenic carbonaceous materials.

The total concentrations of PTEs determined in BMPCM4, BMPCM5, CMPCM4, and CMPCM5 increased 1.4- to 2-fold compared to input feedstock. According to EBC [34], basic grade biochar is characterized by threshold concentrations of $\mathrm{Cd}<1.5 \mathrm{mg} \mathrm{kg}^{-1}, \mathrm{Cu}<100 \mathrm{mg} \mathrm{kg}^{-1}$, and $\mathrm{Zn}<0.4 \mathrm{~g} \mathrm{~kg}^{-1}$. Tested samples of BMPCM4 and BMPCM5 were in accordance with limits. On the other hand, CMPCM4 and CMPCM5 exceeded total concentration of $\mathrm{Zn}$ in terms of the EBC guidelines. DTPA extractable concentrations of PTEs provide important information to estimate the bioavailability of metals and metalloids in soils, sediments, biosolids, and soil amendments [40]. The comparison of DTPA-extractable amounts of $\mathrm{Cd}, \mathrm{Cu}, \mathrm{Fe}$, and $\mathrm{Zn}$ from pyrogenic materials and feedstocks showed a significant decrease in mobile metal forms. Lu et al. [41] revealed similar trends in the mobility of metals from sludge and sludge-derived pyrogenic carbonaceous materials. Reduced mobility of PTEs is attributed to formation on new ligands for metal bindings, and formation of organo-metallic complexes and precipitates. Liu et al. [42] discussed decreased mobility of $\mathrm{Cd}, \mathrm{Cu}$, and $\mathrm{Zn}$ in pyrogenic materials via formation of new chemical forms of metal sulphides and oxides. CAL extraction confirmed a similar trend in the reduction of extractable and mobile phosphorus forms and thus revealed the option to mitigate the P losses in soil matrix. Similar results were confirmed for sewage sludge-derived pyrogenic carbonaceous materials in Frišták et al. [6].

\subsection{Pyrogenic Carbonaceous Materials as Soil Fertilizers}

According to Karayildirim et al. [43], lower pyrolysis temperatures are related to properties more suitable in agricultural applications. The effect of BMPCM4, BMPCM5, CMPCM4, and CMPCM5 at $1 \%$ and $3 \%$ application rates on the habitat choice of Eisenia fetida may be attributable to increased 
water holding capacity and thus higher humidity of amended soil. Busch et al. [44] reported Eisenia spp. preference toward additions of 10 and $30 \mathrm{tha}^{-1}$ of activated peanut hull biochar in loamy sand. Li et al. [45] reported no significant effect of $10 \mathrm{~g} \mathrm{~kg}^{-1}$ of biochar on Eisenia fetida in an avoidance test. Our study confirmed the difference between BMPCM and CMPCM, caused probably by higher water holding capacity of chicken manure-derived materials with minor portion of cellulose material. The relevance of desiccation factor in earthworms' avoidance was highlighted by several authors $[27,45,46]$. Additionally, earthworms are sensitive to the changes in the matrix potential of the soil [27]. Our study showed BMPCM material as a product with higher content of removable ash compared to CMPCM product. The addition of small-sized PCM particles into soil can slightly increase the soil porosity or, on the other hand, fill macroscopic soil pores. This can alter particle contacts and degree of water saturation in soil.

Application of $1 \%$ and 3\% BMPCM4, BMPCM5, CMPCM4, and CMPCM5 in pot experiments with rye seedlings showed differences in plant biomass production and thus in total $\mathrm{P}$ concentrations accumulated in rye aboveground tissues. Pyrogenic materials can be utilized as slow-releasing fertilizers with mitigation of $\mathrm{P}$ losses compared to original feedstock application. Our results showed decreased lower or statistically non-significant differences between control and amended samples for $\mathrm{Cd}$ and $\mathrm{Cu}$ accumulation. Fe showed a similar trend. Total concentrations of $\mathrm{Zn}$ in rye tissues were higher at CMPCM4 and CMPCM5 amendments compared to control. This can be attributed to higher concentrations of $\mathrm{Zn}$ in chicken manure-derived pyrogenic materials compared to bone meal-derived pyrogenic materials. The reducing availability of PTEs by rye roots can be discussed as a liming effect of pyrogenic materials. Given the known effect of $\mathrm{pH}$ on solubility and thus mobility of several elements [25], the effect of pyrogenic material application on soil $\mathrm{pH}$ has a stronger significance than these elements' original concentrations in amendments. A similar trend was confirmed by Hass et al. [14] for chicken manure-derived biochar and availability of several PTEs. Our previous study [6] showed a decrease in availability of $\mathrm{Cd}, \mathrm{Cr}, \mathrm{Cu}, \mathrm{Ni}$, and $\mathrm{Pb}$ for alfalfa in soil-amended $1 \%$ and $5 \%$ sludge-derived pyrogenic carbonaceous materials. Additionally, bioaccumulation of $\mathrm{Zn}$ by alfalfa showed an opposite trend to other PTEs.

\section{Conclusions}

The results showed that pyrogenic carbonaceous materials produced from chicken manure and bone meal can be applied as potential alternative $\mathrm{P}$ fertilizers and soil organic $\mathrm{C}$ stabilization tools. The pyrolysis products produced at $500{ }^{\circ} \mathrm{C}$ contained lower concentrations of mobile forms of PAHs in comparison with materials produced at $400^{\circ} \mathrm{C}$. Total carbon content decreased in the order of BM $>$ BMPCM4 > BMPCM5 and increased in the order of CM < CMPCM4 < CMPCM5. We observed enhanced total $\mathrm{P}$ content in pyrogenic materials compared to input feedstocks. Available forms of $\mathrm{P}$ and PTEs decreased with the increase of pyrolysis temperature. Rye seedling test showed comparable or enhanced accumulation of phosphorus from pyrogenic materials compared to inorganic fertilizers. Comparison of chicken manure-derived pyrogenic carbonaceous materials and bone meal-derived pyrogenic carbonaceous materials applied in 1\% and 3\% amendments showed better preference of Eisenia foetita for a higher application rate. Obtained results of short-term experiments require a comparison with long-term field experiments to assess pyrogenic material application as commercial fertilizers. However, production of pyrogenic carbonaceous materials by thermochemical conversion of bone meal and chicken manure shows a promising tool in assessment of heterogeneous feedstocks as valuable soil amendments.

Author Contributions: Conceptualization, V.F. and M.P.; methodology, V.F. and G.S.; validation, V.F. and G.S., formal analysis, V.F.; investigation, V.F., A.K.P., M.H., and M.K.; writing-original draft preparation, V.F.; writing-review and editing, V.F. and A.K.P.; visualization, V.F.; supervision, V.F. and G.S.; project administration, V.F., M.P., and G.S.; funding acquisition, V.F., M.P., and G.S. 
Funding: This research was funded by Austrian Research Promotion Agency FFG, project number 844744; Scientific Grant Agency of the Ministry of Education, Science, Research and Sport of the Slovak Republic, project number VEGA1/0110/19; and Trnava University in Trnava, project number 2/TU/2019.

Acknowledgments: Authors are thankful to M.Sc. Marion Graser and Christian Mayer for technical support and M.Sc. David Erwin Berthold for language proofs.

Conflicts of Interest: The authors declare no conflict of interest. The funders had no role in the design of the study; in the collection, analyses, or interpretation of data; in the writing of the manuscript, or in the decision to publish the results.

\section{References}

1. Jones, A.; Panagos, P.; Barcelo, S.; Bouraoui, F.; Bosco, C.; Dewitte, O.; Gardi, C.; Erhard, M.; Hervás, J.; Hiederer, R.; et al. The State of Soil in Europe. In Reference Report by the Joint Research Centre; European Union: Brussels, Belgium, 2012.

2. Micháleková-Richveisová, B.; Frišták, V.; Pipíška, M.; Ďuriška, L.; Moreno-Jiménez, E.; Soja, G. Iron-impregnated biochars as effective phosphate sorption materials. Environ. Sci. Pollut. Res. Int. 2017, 24, 463-475. [CrossRef]

3. Cordell, D.; White, S. Peak phosphorus: Clarifying the key issues of a vigorous debate about long-term phosphorus security. Sustainability 2011, 3, 2027-2049. [CrossRef]

4. Lehmann, J.; Rillig, M.C.; Thies, J.; Masiello, C.A.; Hockaday, W.C.; Crowley, D. Biochar effects on soil biota-A review. Soil Biol. Biochem. 2011, 43, 1812-1836. [CrossRef]

5. Kloss, S.; Zehetner, F.; Wimmer, B.; Buecker, J.; Rempt, F.; Soja, G. Biochar application to temperate soils: Effects on soil fertility and crop growth under greenhouse conditions. J. Plant Nutr. Soil Sci. 2014, 177, 3-15. [CrossRef]

6. Frišták, V.; Pipíška, M.; Soja, G. Pyrolysis treatment of sewage sludge: A promising way to produce phosphorus fertilizer. J. Clean. Prod. 2018, 172, 1772-1778. [CrossRef]

7. Dieguez-Alonso, A.; Anca-Couce, A.; Frišták, V.; Moreno-Jiménez, E.; Bacher, M.; Bücheli, T.D.; Cimò, G.; Conte, P.; Hagemann, N.; Haller, A.; et al. Designing biochar properties through the blending of biomass feedstock with metals: Impact on oxyanions adsorption behavior. Chemosphere 2019, 214, 743-753. [CrossRef]

8. Aceña-Heras, D.; Novak, J.; Luz Cayuela, M.; Peñalosa, J.M.; Moreno-Jiménez, E. Influence of pyrolyzed grape-seeds/sewage sludge blends on the availability of $\mathrm{P}, \mathrm{Fe}, \mathrm{Cu}, \mathrm{As}$ and $\mathrm{Cd}$ to maize. Agronomy 2019, 9, 406. [CrossRef]

9. Víglašová, E.; Galamboš, M.; Danková, Z.; Krivosudský, L.; Lengauer, L.C.; Hood-Nowotny, R.; Soja, G.; Rompel, A.; Matík, M.; Briančin, J. Production, characterization and adsorption studies of bamboo-based biochar/montmorillonite composite for nitrate removal. Waste Manag. 2018, 79, 385-394. [CrossRef]

10. Mayer, P.; Hilber, I.; Gouliarmou, V.; Hale, S.E.; Cornelissen, G.; Bucheli, T.D. How to determine the environmental exposure of PAHs originating from biochar. Environ. Sci. Technol. 2016, 50, 1941-1948. [CrossRef]

11. Hilber, I.; Blum, F.; Leifeld, J.; Schmidt, H.P.; Bücheli, T.D. Quantitative determination of PAHs in biochar:a prerequisite to ensure its quality and safe application. J. Agric. Food Chem. 2012, 60, 3042-3050. [CrossRef]

12. Buss, W.; Mašek, O. Mobile organic compounds in biochar-A potential source of contamination-Phytotoxic effects on cress seed (Lepidum sativum) germination. J. Environ. Manag. 2014, 137, 111-119. [CrossRef] [PubMed]

13. Wang, J.; Xia, K.; Waigi, M.G.; Gao, Y.; Odinga, E.S.; Ling, W.; Liu, J. Application of biochar to soils may result in plant contamination and human cancer risk due to exposure of polycyclic aromatic hydrocarbons. Environ. Int. 2018, 121, 169-177. [CrossRef] [PubMed]

14. Hass, A.; Gonzalez, J.M.; Lima, I.M.; Godwin, H.W.; Halvorson, J.J.; Boyer, D.G. Chicken manure biochar as liming and nutrient source for acid Appalachian soil. J. Environ. Qual. 2012, 41, 1096-1106. [CrossRef] [PubMed]

15. Frišták, V.; Graser, M.; Pipíška, M.; Micháleková-Richveisová, B.; Soja, G. Pyrolysis products as soil fertilizers: Screening of potentially hazardous aromatic compounds. Nova Biotechnol. Chim. 2016, 15, 35-46. [CrossRef]

16. Hazardous Wastes EWC Codes 1001 and 1901, CWC Codes 1001 and 1901, Council decision 22/12/94 (94/904/EC). In European Community Council Directive 91/96/WC; European Union: Brussel, Belgium, 1994. 
17. Vamvuka, D.; Dermitzakis, S.; Pentari, D.; Sfakiotakis, S. Valorization of meat and bone meal through pyrolysis for soil amendment or lead adsorption from wastewaters. Food Bioprod. Process. 2018, 109, $148-157$. [CrossRef]

18. Someus, E.; Pugliese, M. Concentrated phosphorus recovery from food grade animal bones. Sustainability 2018, 10, 2349. [CrossRef]

19. Siebers, N.; Leinweber, P. Bone Char: A clean and renewable phosphorus fertilizer with cadmium immobilization capacity. J. Environ. Qual. 2013, 42, 405-411. [CrossRef]

20. Cely, P.; Gascó, G.; Paz-Ferreiro, J.; Méndez, A. Agronomic properties of biochars from different manure wastes. J. Anal. Appl. Pyrolysis 2015, 111, 173-182. [CrossRef]

21. EPIWIN; Version 3.10; US EPA (US Environmental Protection Agency) and SRC (Environmental Science Center): Washington, DC, USA, 2000.

22. Búcheli, T.; Blum, F.; Desaules, A.; Gustafsson, O. Polycyclic aromatic hydrocarbons, black carbon, and molecular markers in soil of Switzerland. Chemosphere 2004, 56, 1061-1076. [CrossRef]

23. Richardson, S.D.; Aitken, M.D. Desorption and bioavailability of polycyclic aromatic hydrocarbons in contaminated soil subjected to long-term in situ biostimulation. Environ. Toxicol. Chem. 2011, 30, 2674-2681. [CrossRef]

24. Frišták, V.; Laughinghouse, H.D.; Packová, A.; Graser, M.; Soja, G. Monitoring of methylated naphthalenes in sludge-derived pyrogenic carbonaceous materials. Chemosphere 2019, 217, 456-462. [CrossRef] [PubMed]

25. Lindsay, W.L.; Norvell, W.A. Development of a DTPA soil test for zinc, iron, manganese, and copper. Soil Sci. Soc. Am. J. 1978, 42, 419-428. [CrossRef]

26. Hund-Rinke, K.; Wiechering, H. Earthworms avoidance test for soil assessments: An alternative for acute and reproduction tests. J. Soils Sediments 2001, 1, 15-20. [CrossRef]

27. Tammeorg, P.; Parviainen, T.; Nuutinen, V.; Simojoki, A.; Vaara, E.; Helenius, J. Effects of biochar on earthworms in arable soil: Avoidance test and field trial in boreal loamy sand. Agric. Ecosyst. Environ. 2014, 191, 150-157. [CrossRef]

28. Organization for Economic Co-Operation and Development. Test No. 207: Earthworm Acute Toxicity Test. In OECD Guideline for Testing of Chemicals, Section 2; OECD: Paris, France, 1984.

29. Enders, A.; Lehmann, J. Comparison of wet-digestion and dry-ashing methodsfor total elemental analysis of biochar. Commun. Soil Sci. Plant Anal. 2012, 43, 1042-1052. [CrossRef]

30. Schüller, H. Die CAL-Methode, eine neude Methode zur Bestimmung des pflanzen verfügbaren Phosphates in Böden. J. Plant Nutr. Soil Sci. 1969, 123, 48-63.

31. Neubauer, H.; Schneider, W. The nutrient uptake of seedlings and its application for the estimation of the nutrient content in soils. Z. Pflanzenernähr. Düng. Bodenk. 1923, A2, 329-362.

32. Agrafioti, E.; Bouras, G.; Kalderis, D.; Diamadopoulos, E. Biochar production by sewage sludge pyrolysis. J. Anal. Appl. Pyrolysis 2013, 101, 72-78. [CrossRef]

33. Amonette, J.; Joseph, S. Characteristics of Biochar: Micro Chemical Properties. In Biochar for Environmental Management: Science and Technology; Lehmann, J., Joseph, S., Eds.; Earthscan: London, UK, 2009; pp. 33-52.

34. Cantrell, K.B.; Hunt, P.G.; Uchimiya, M.; Novak, J.M.; Ro, K.S. Impact of pyrolysis temperature and manure source on physicochemical characteristics of biochar. Bioresour. Technol. 2012, 107, 419-428. [CrossRef]

35. EBC. European Biochar Certificate, Guidelines for a Sustainable Production of Biochar; European Biochar Foundation: Arbaz, Switzerland, 2012.

36. Dai, Q.; Jiang, X.; Jiang, Y.; Jin, Y.; Wang, F.; Chi, Y.; Yan, J.; Xu, A. Temperature influence and distribution in three phases of PAHs in wet sewage sludge pyrolysis using conventional and microwave heating. Energy Fuels 2014, 28, 3317-3325. [CrossRef]

37. Búcheli, T.; Hilber, I.; Schmidt, H.P. Polycyclic aromatic hydrocarbons and polychlorinated aromatic compounds in biochar. In Biochar for Environmental Management. Science and Technology and Implementation; Routledge: Abingdon-on-Thames, UK, 2015; pp. 595-624.

38. Zielińska, A.; Oleszczuk, P. The conversion of sewage sludge into biochar educes polycyclic aromatic hydrocarbon content and ecotoxicity but increases trace metal content. Biomass Bioenergy 2015, 75, 235-244. [CrossRef]

39. Oleszczuk, P. The tenax fraction of PAHs relates to effects in sewage sludges. Ecotoxicol. Environ. Saf. 2009, 72, 1320-1325. [CrossRef] [PubMed] 
40. Karer, J.; Wawra, A.; Zehetner, F.; Dunst, G.; Wagner, M.; Pavel, P.B.; Puschenreiter, M.; Friesl-Hanl, W.; Soja, G. Effects of biochar and compost mixtures and inorganic additives on immobilisation of heavy metals in contaminated soils. Water Air Soil Pollut. 2015, 226, 342. [CrossRef]

41. Lu, H.; Zhang, W.; Wang, S.; Zhuang, L.; Yang, Y.; Qiu, R. Characterization of sewage sludge-derived biochars from different feedstocks and pyrolysis temperatures. J. Anal. Appl. Pyrolysis 2013, 102, 137-143. [CrossRef]

42. Liu, T.; Liu, B.; Zhang, W. Nutrients and heavy metals in biochar produced by sewage sludge pyrolysis: Ist application in soil amendment. Pol. J. Environ. Stud. 2014, 23, 271-275.

43. Karayildirim, T.; Yanik, J.; Yuksel, M.; Bock-Horn, H. Characterization of products from pyrolysis of waste sludges. Fuel 2006, 85, 1498-1508. [CrossRef]

44. Busch, D.; Kammann, C.; Grünhage, L.; Muller, C. Simple biotoxicity tests for evaluation of carbonaceous soil additives: Establishment and reproducibility of four test procedures. J. Environ. Qual. 2011, 40, 1-10. [CrossRef]

45. Li, D.; Hockaday, W.C.; Masiello, C.A.; Alvarez, P.I.J. Earthworms avoidance of biochar can be mitigated by wetting. Soil Biol. Biochem. 2011, 43, 1732-1737. [CrossRef]

46. Chan, K.Z.; Barchia, I. Soil compaction controls the abundance, biomass and distribution of eartworms in a single dairz farm in south-eastern Australia. Soil Tillage Res. 2007, 94, 75-82. [CrossRef]

(C) 2019 by the authors. Licensee MDPI, Basel, Switzerland. This article is an open access article distributed under the terms and conditions of the Creative Commons Attribution (CC BY) license (http://creativecommons.org/licenses/by/4.0/). 